\title{
Factor Prices and Productivity Growth During the British Industrial Revolution
}

\section{Citation}

Antras, Pol and Hans-Joachim Voth. 2003. Factor prices and productivity growth during the British industrial revolution. Explorations in Economic History 40(1): 52-77.

\section{Published Version}

http://dx.doi.org/10.1016/S0014-4983(02)00024-4

\section{Permanent link}

http://nrs.harvard.edu/urn-3:HUL.InstRepos:3199066

\section{Terms of Use}

This article was downloaded from Harvard University's DASH repository, and is made available under the terms and conditions applicable to Other Posted Material, as set forth at http:// nrs.harvard.edu/urn-3:HUL.InstRepos:dash.current.terms-of-use\#LAA

\section{Share Your Story}

The Harvard community has made this article openly available.

Please share how this access benefits you. Submit a story.

\section{Accessibility}




\title{
FACTOR Prices AND Productivity GroWTH DURING THE BRITISH INDUSTRIAL REVOLUTION
}

\author{
Pol Antràs \\ Hans-Joachim Voth ${ }^{* *}$
}

\begin{abstract}
This paper presents new estimates of total factor productivity growth in Britain for the period 1770-1860. We use the dual technique and argue that the estimates we derive from factor prices are of similar quality to quantity-based calculations. Our results provide further evidence, calculated on the basis of an independent set of sources, that productivity growth during the British Industrial Revolution was relatively slow. The Crafts-Harley view of the Industrial Revolution is thus reinforced. Our preferred estimates suggest an even modest acceleration after 1800.
\end{abstract}

JEL classification: N13, O47, O52

Key words: British Industrial Revolution, productivity growth, dual measurement of productivity.

This Draft: August $19^{\text {th }}, 2002$

Final Version: Explorations in Economic History, 40 (1), January 2003, pp. 52-77.

Acknowledgments: The authors would like to thank Daron Acemoglu, Lucia Breierova, Albert Carreras, Nick Crafts, Charles Feinstein, Oded Galor, Jonas Ljungquist, Peter Temin, Jaume Ventura, Tony Wrigley and two anonymous referees for their suggestions. We are especially grateful to Joel Mokyr and Eugene White for their observations and advice. Seminar audiences at Brown, MIT, the Institute for Advanced Study at ANU, UC Davis and the EU Workshop on Technical Change, Economic Growth, and Convergence, Lund-Mölle offered insightful comments. Research for this project was carried out while Hans-Joachim Voth was in receipt of a Philip Leverhulme Prize Fellowship. Pol Antràs gratefully acknowledges financial support from the Bank of Spain.

\footnotetext{
${ }^{*}$ Economics Department, MIT, Cambridge, MA. email: pol@mit.edu.

** Economics Department, MIT, Cambridge, MA; Universitat Pompeu Fabra, Barcelona; Centre for History and Economics, King's College, Cambridge, UK. email: hjv23@cam.ac.uk
} 


\section{Introduction}

How rapid was productivity growth during the Industrial Revolution? Since the pioneering studies of Ashton (1948) as well as Deane and Cole (1962), this question has been central to the economic history of Britain, 1750-1850. It is also of wider interest for the speed and timing of productivity changes following major inventions. After the introduction of electric motors and the computer, for example, productivity performance remained sluggish for decades. When it did pick up, total factor productivity (TFP) increases were rapid and widespread. Of course, technological change need not be mirrored in TFP growth. As the recent work of the Boskin commission and of Nordhaus demonstrates, traditional measures such as price indices may miss substantial product innovation altogether. ${ }^{1}$ Yet it is important to examine how TFP changes during and after major inventions. Recent examples of slow productivity growth and rapid technical progress may not be aberrations, but could form part of a regular pattern if we can also demonstrate convincingly that England did not become much more efficient during the first few decades of the Industrial Revolution. ${ }^{2}$

Crafts and Harley have estimated modest rates of output growth during the Industrial Revolution. ${ }^{3}$ Crafts found that Deane and Cole (1962) had chosen an inappropriate price index with which to deflate the nominal income series in the national accounts, thus overstating growth. He also compiled alternative indices for agricultural, industrial and service output. His finding of substantially slower growth was reinforced by Harley, who argued that that the earlier estimates of industrial production by Hoffmann (1955) had seriously overestimated growth (by giving too high a weight to the revolutionary cotton sector). Since rates of input growth have not been similarly revised downwards, their results also imply that the Solow residual was only growing relatively slowly during the late eighteenth and early nineteenth century. ${ }^{4}$

Deane and Cole did not provide any estimates of total factor productivity growth during the industrial revolution. Later work by Feinstein (1981), however, showed that

\footnotetext{
${ }^{1}$ Boskin et al. (1998). Nordhaus (1997).

${ }^{2}$ David (1990).

${ }^{3}$ Crafts (1985), Harley (1982), Crafts and Harley (1992).

${ }^{4}$ Voth (1998) revises the labour input figures based on a sharp rise in working hours.
} 
Deane and Cole's estimates implied remarkably rapid total factor productivity growth, especially for the period 1801-1831. ${ }^{5}$ Using the standard, primal approach to growth accounting, Feinstein estimated annual productivity growth of $0.2 \%$ for the period 1760 1800 and of $1.3 \%$ for the period 1801-1830. The latest calculations by Crafts and Harley, based on their revised output series, imply increases of only $0.1 \%$ p.a. during $1760-1800$ and $0.35 \%$ p.a. during 1800-1830 (Table 1). The new orthodoxy thus holds that both output and productivity growth were slow during the English Industrial Revolution. Also, advances were heavily concentrated in the 'revolutionizing sectors' such as cotton and iron manufacturing. These sectors were too small to have a sizeable impact on the manufacturing sector as a whole (and the economy at large) until the middle of the 19th century. What was 'revolutionary' about the Industrial Revolution was neither the speed of output growth nor its cause, but a broad structural transformation, reallocating labour from agriculture to industry.

Table 1: Previous Estimates of Productivity Growth in England, 1760-1831

\begin{tabular}{|c|c|c|c|c|c|}
\hline $\begin{array}{r}\text { annual percentage } \\
\text { rate of change }\end{array}$ & $\mathbf{Y}$ & $\mathbf{K}$ & $\mathbf{L}$ & $\mathbf{T}$ & TFP \\
\hline \multicolumn{6}{|l|}{ Feinstein (1981) } \\
\hline $1760-1800$ & 1.1 & 1 & 0.8 & - & 0.2 \\
\hline $1801-1831$ & 2.7 & 1.4 & 1.4 & - & 1.3 \\
\hline $1831-1860$ & 2.5 & 2.0 & 1.4 & & 0.8 \\
\hline \multicolumn{6}{|l|}{ Crafts (1985) } \\
\hline $1760-1800$ & 1 & 1 & 0.8 & 0.2 & 0.2 \\
\hline $1801-1831$ & 2 & 1.5 & 1.4 & 0.4 & 0.7 \\
\hline $1831-1860$ & 2.5 & 2.0 & 1.4 & 0.6 & 1.0 \\
\hline \multicolumn{6}{|l|}{ Crafts/Harley (1992) } \\
\hline $1760-1801$ & 1 & 1 & 0.8 & - & 0.1 \\
\hline $1801-1831$ & 1.9 & 1.7 & 1.4 & - & 0.35 \\
\hline $1831-1860$ & 2.5 & 2 & 1.4 & & 0.8 \\
\hline
\end{tabular}

Note: Based on the figures in Harley (1999b, p. 183) adapted to the two-factor-case.

The new orthodoxy established by Crafts and Harley has attracted criticism from different perspectives. ${ }^{6}$ All contributors to the literature on the speed of output and productivity growth emphasize the fragility of the underlying data. As Feinstein said of

\footnotetext{
${ }_{5}^{5}$ Feinstein's revisions of Deane and Cole's estimates concentrated on the figures on capital formation. See Feinstein and Pollard (1988) for more on this issue.
} 
his estimates of capital formation - "we are able to proceed only by reliance on conjecture and speculation." ${ }^{, 7}$ Some critics of the dominant view argue that data revisions and changes in procedure should substantially modify it; others doubt the value of the exercise as such, given the limitations of the data and the number of non-quantitative aspects necessarily excluded. Berg and Hudson firmly fall into the second category. They emphasize demographic change, regional specialization, organizational changes and the evolution of female and child labour as areas that showed truly 'revolutionary' change. They also voice a general distrust of aggregate, quantity-based output and TFP calculations, and point to some potential sources of fragility of the estimates derived such as the assumption of constant returns to scale. ${ }^{8}$ Their plea for the inclusion of nonquantitative evidence, and their sceptical evaluation of Crafts's and Harley's data work is in part a continuation of Julian Hoppit's critique. He emphasized the difficulties of applying appropriate weights to the output series of individual industries. This is normally based on value-added, evidence on which is relatively fragile. ${ }^{9}$

Other critics have attempted to rework the original data, or to add new evidence. R.V. Jackson argues for higher weights for faster-growing industries. ${ }^{10}$ Based on a reexamination of the Crafts-Harley data set, he challenges the view that industrial output growth did not accelerate until the second decade of the nineteenth century. ${ }^{11}$ His series of industrial output suggests a break in the trend rate of growth as early as the 1780s. Overall, however, his index is not too different from the one proposed by Crafts and Harley, and they have accepted his estimates as a possible alternative interpretation of the data. ${ }^{12}$ Cuenca Esteban $(1994,1995)$ has attempted to use additional information on the price of cotton goods derived from contemporary customs estimates to argue that Crafts and Harley have understated the growth of cotton output. Overall output growth for England would be markedly higher if his corrected figures for textile production are used.

\footnotetext{
${ }^{6}$ The most comprehensive overview of the debate is Mokyr (1999).

${ }^{7}$ Feinstein (1981).

${ }^{8}$ Berg and Hudson (1992).

${ }^{9}$ Hoppit (1990).

${ }^{10}$ Jackson (1990) also argues that there is a mistake in Crafts's original calculation of the output in commerce, which Crafts and Harley (1992) accept.

${ }^{11}$ Jackson (1992). Crafts and Harley (1992) contend that, contrary to Jackson's argument, any revision would have to be downwards.

${ }^{12}$ Crafts and Harley (1992).
} 
Crafts and Harley have defended their estimates. ${ }^{13}$ Cuenca Esteban's alternative index is not generally accepted as a superior measure of changing cotton prices. ${ }^{14}$

Finally, Temin has used a novel approach to lend credence to the idea that productivity advances were relatively wide-spread. He analysed the pattern of British trade during the period to examine revealed comparative advantage. While not calculating TFP directly, Temin argues that slow (and heavily concentrated) productivity growth should have turned England into a net importer of most manufactured goods. ${ }^{15}$ Since Britain continued to export most industrial goods, he rejects the notion of limited and minimal productivity advances. Crafts and Harley (2000) use a CGE-model to show that the trade data can be reconciled with concentrated (and slow) productivity growth, generating some puzzling implications in the process. ${ }^{16}$

The marked improvements in quantity-based national accounts over the past 20 years - especially in the case of capital inputs and overall output measurement - have therefore not led to an unquestioned consensus. Independent of the merits of individual challenges, continuing debate over the core elements of the Crafts-Harley view shows that what is needed are new results based on additional data, using a different technique to extract information from the same set of underlying methodological assumptions. In this paper, we use a dual approach to derive independent estimates of TFP growth during the English Industrial Revolution. Based on factor prices, we show that there is clear evidence of slow productivity growth. Using an unrelated method and independent data, the main aspects of the new orthodoxy still emerge, thus adding to our confidence in the Crafts-Harley view. Section 2 briefly introduces the dual approach to TFP accounting, and argues that in the case of historical data, it will yield estimates that are at least as reliable as those derived from the primal approach. We then discuss the data sources used in our calculations. Section 3 presents our new estimates of TFP growth, and confronts these with existing calculations. In Section 4, we conduct a number of sensitivity tests. We conclude with some observations on the wider implications of our findings.

\footnotetext{
${ }^{13}$ Harley and Crafts (1995); Harley (1999a).

${ }^{14}$ Honeyman (1996).

${ }^{15}$ Temin $(1997,2000)$.

${ }^{16}$ Temin (2000).
} 


\section{A Dual Approach to Productivity during the Industrial Revolution}

Using input and output prices (instead of quantities) to measure changes in productivity is not a novel idea. Griliches and Jorgenson demonstrated the equivalence of the primal and dual approaches to growth accounting. ${ }^{17}$ An early application of the dual approach to economic history can be found in McCloskey, who inferred changes in agricultural productivity during the industrial revolution from movements in rents paid for land. ${ }^{18}$ Recently, Clark has extended McCloskey's technique by also considering changes in farm wages and return on farm capital, deriving overall measures of productivity change in agriculture. ${ }^{19}$

The dual approach has also been used to measure productivity in manufacturing during the Industrial Revolution. McCloskey analysed output and input price data in several industrial sectors to infer annual productivity change between 1780 and 1860 . He summarized the intuition behind the dual approach thus: "We do not know annual quantities of china plates and steam coal, ... and probably never can. On the other hand, we know practically anything we choose about price. ... The technique is to measure physical productivity change by the changes in prices ... The degree to which the price of the cloth fell relative to the price of the inputs is therefore a measure of productivity change. ${ }^{20}$ Productivity advances will eventually bid up the price of factors of production, as they must in a competitive economy. The extent to which capital, labour and land can receive higher payments is a direct measure of the pace of productivity advances.

The same argument can be made for the economy as a whole. If the remuneration of all factors of production increases, overall output must be growing. A similar intuition lies behind the use of value-added in constructing national accounts. We will assume that there are only three factors of production in the economy: labor (L), capital (K) and land (T). Thus, at any given date $\mathrm{t}$, output $(\mathrm{Y})$ will be a function of $\mathrm{K}, \mathrm{L}$ and $\mathrm{T}$ at date $\mathrm{t}$ :

$$
\mathrm{Y}_{\mathrm{t}}=\mathrm{F}\left(\mathrm{K}_{\mathrm{t}}, \mathrm{L}_{\mathrm{t}}, \mathrm{T}_{\mathrm{t}}\right)
$$

\footnotetext{
${ }^{17}$ Griliches and Jorgenson (1967).

${ }^{18}$ McCloskey (1972, pp. 32-33).

${ }^{19}$ Clark (1999).

${ }^{20}$ McCloskey (1994, pp. 250-1).
} 
Following Hsieh (1999), our derivation of the dual estimates of productivity growth is based on the national income accounting identity that the (real) value of national output has to be equal to the (real) payments to the factors, i.e.:

$$
\mathrm{Y}_{\mathrm{t}}=\mathrm{r}_{\mathrm{t}} \mathrm{K}_{\mathrm{t}}+\mathrm{w}_{\mathrm{t}} \mathrm{L}_{\mathrm{t}}+\mathrm{q}_{\mathrm{t}} \mathrm{T}_{\mathrm{t}}
$$

where $\mathrm{w}, \mathrm{r}$ and $\mathrm{q}$ are real wages, the real rental rate of capital and real agricultural rents respectively. ${ }^{21}$ Taking logarithms and differentiating with respect to time we obtain the following expression

$$
\hat{Y}=\eta_{K}(\hat{r}+\hat{K})+\eta_{L}(\hat{w}+\hat{L})+\eta_{T}(\hat{q}+\hat{T})
$$

where hats indicate growth rates and $\eta$ is the share of income going to each factor. ${ }^{22}$ Rearranging we obtain:

$$
\hat{Y}-\eta_{K} \hat{K}-\eta_{L} \hat{L}-\eta_{T} \hat{T}=\eta_{K} \hat{r}+\eta_{L} \hat{w}+\eta_{T} \hat{q}
$$

Note that the left-hand side of equation (4) is just the usual (primal) expression for the Solow residual, that is, the difference between the growth rate of output and a weightedsum of the growth rates of factor inputs, with the weights being the shares of each input in total income. The right-hand side of equation (4), our dual measure of total factor productivity growth, is equal to the weighted-sum of the growth rates of real factor prices. $^{23}$ Summarizing, we have obtained $T F P_{\text {Primal }}=T F P_{\text {Dual }}=\eta_{K} \hat{r}+\eta_{L} \hat{w}+\eta_{T} \hat{q}$ which will be the expression we use throughout this paper to obtain our measures of productivity growth in England between 1770 and 1860. Although it should be clear from the above derivation, we should stress the fact that the equality between the primal and dual approaches to growth accounting simply follows from an identity.

This however does not imply that our measure of productivity is flawless. In fact, in order for the right-hand side of equation (4) to truthfully measure total factor pro-

\footnotetext{
${ }^{21}$ Notice that no assumption is needed (other than that labor, capital and land are the only three factors of production) to obtain equation (2).

${ }^{22}$ We use log differences to compute growth rates.

${ }^{23}$ If we had used nominal values, this would be equal to the difference between the weighted-sum of growth rates and the growth rate of output prices.
} 
ductivity we further need to assume perfect competition and constant returns to scale. In the presence of imperfect competition, technological progress that is not Hicks-neutral, or increasing returns to scale, factors of production would not be paid the value of their marginal product and dual estimates of total factor productivity could be shown to be biased. ${ }^{24}$ However, and this is a crucial point, if the above assumptions are violated, primal measures of productivity will be biased by the same amount since, as discussed above, primal and dual estimates are theoretically equivalent. ${ }^{25}$

Hence, any difference between the primal and dual approaches has to stem from an inconsistency between the national accounts and the data on factor prices. One potential shortcoming - that, again, would affect primal and dual estimates - should be mentioned at the outset. If we assume an alternative production function, with an additional factor such entrepreneurship or productive knowledge, our estimates might be biased downwards. This is because we would fail to measure the additional return received by this factor. ${ }^{26}$ Given the difficulty of measuring returns to such factors of production, this may be impossible to remedy. There is some indirect evidence that such a development might have been at work during the Industrial Revolution. Feinstein (1998b) shows that GDP grew faster over the period than real wages, which suggests that other factors of production received a growing slice of the pie. If our rates of increase in the remuneration of capital and land are not showing greater increases than real wages, the limitations of using a production function with three factors may partly be responsible.

Note that, in some ways, using the dual approach reduces the impact of entrepreneurial quasi-rents in transitions between different equilibria. These are generally difficult to capture using national income accounting, but dual measurement at the level of the economy at large minimizes their influence. In the case of cotton, for example, one could argue about the extent to which a gradual erosion of the high rents captured by the first generation of producers was responsible to the output price decline relative to inputs. If cotton producers earned higher than average returns on their capital, we would be in

\footnotetext{
${ }^{24}$ Hsieh $(2000,2002)$.

${ }^{25}$ In the primal approach, the bias would come from the fact that, if factors are not paid their marginal product, factor shares are no longer equal to the elasticity of output with respect to each factor. Cf. Crafts and Harley (1992) in response to this kind of criticism by Berg and Hudson (1992).
} 
danger of overestimating the rate of productivity change. ${ }^{27}$ For the economy as a whole, of course, the influence of sector-specific rents or innovation premia will be much smaller - and estimating the rental price of capital is correspondingly less problematic. Note also the direction of bias. Since the cotton industry by the middle of the 19th century was a highly competitive industry, with hundreds of small- and medium-sized producers, any rents that might initially have existed had probably largely disappeared by 1850. Any decline in price would therefore be the result of higher productivity and a reduction in monopoly power. The larger innovation premia were in the beginning, and the faster they declined, the greater the upward bias of our estimates of TFP growth will be.

Previous studies have mostly analysed particular sectors of the economy (e.g. agriculture, cotton), using input and output price data from these particular sectors to infer productivity changes. The difference between this previous 'dual' literature and this paper is one of scope. Our approach focuses on the economy as a whole. Recent contributions by Feinstein, Turner, Beckett and Afton and Clark have provided aggregate national series for wages and rents in England during the industrial revolution. ${ }^{28}$ We take advantage of these contributions to construct a dual estimate of aggregate total factor productivity growth in England in the period 1770-1860. The exercise that is most closely related to ours is Clark (2001b), who also uses factor prices to calculate TFP growth in England. ${ }^{29}$ The next section describes the data in more detail, and presents the most important results.

\section{Data and Results}

Our approach requires data on the evolution of prices, the rental cost of capital, the cost of labour, and the return to land. Choosing a series for wages is easier than for any other components that we require. Feinstein's (1998) series is the definitive contribution to the

\footnotetext{
${ }^{26}$ Hsieh (2002).

27 Assuming that measures of the return on capital for the economy as a whole are used in calculating sectoral productivity growth.

${ }^{28}$ Feinstein (1998a), Turner, Beckett and Afton (1997), and Clark (1998, 2002).

${ }^{29}$ Clark's main aim, however, is not to use factor prices as independent evidence on TFP growth rates. Instead, he offers a broad interpretation of the long-term development of the British economy.
} 
literature, replacing the earlier indices compiled by Lindert and Williamson (1983). ${ }^{30}$ Feinstein's estimates of average nominal earnings in Great Britain relate to manual (bluecollar) workers and exclude salaried (white-collar) workers. Lindert and Williamson (1983) restricted their study to England, but also considered white-collar workers. Although these two studies sustain opposite views on the living standards issue, Lindert and Williamson's nominal wage series for blue-collar workers is remarkably similar to the Feinstein data. Most of the difference between these authors' views arises as a result of the use of different price indices. Since all the price indices for our period are highly imperfect, we also use the Lindert and Williamson index in our sensitivity tests. ${ }^{31}$ Feinstein's new index is considerably more comprehensive, covering 24 different occupations or industries that employed 4 out of 5 Britons in 1851. His inclusion of Scotland may bias our results in favor of finding faster productivity growth, since growth there was probably faster than in England.

It could be argued that a rising proportion of unskilled workers in the workforce exerted downward pressure on wages as measured by real wage indices. ${ }^{32}$ Feinstein's series implicitly assumes that all changes in skill are incorporated in the level of average earnings. ${ }^{33}$ Controlling for the possible effects of changes in the skill composition of the workforce would clearly be desirable. Other studies eliminate the effect of changes in the skill composition by using separate wage series for each skill category. We decided not to correct wage changes for human capital formation. This is because the size and trend of skill premia during the Industrial Revolution are highly uncertain, and there is little evidence that the skills of the workforce changed rapidly. ${ }^{34}$ Also, changes in the number of hours worked per day should be taken into account in our productivity calculations. However, since most of the changes in total hours of labor input during this period were caused by more days of work (and not changes in hours per day), this is unlikely to be a source of confusion. ${ }^{35}$

\footnotetext{
${ }^{30}$ We use the average full employment money earnings for Great Britain, Feinstein (1998a, Appendix Table 1, p. 652).

${ }^{31}$ In this way, the use of the Lindert-Williamson series provides us with an upper bound. Cf. Clark (2001b).

${ }^{32}$ We thank Daron Acemoglu for this suggestion.

${ }^{33}$ Feinstein (1996).

${ }^{34}$ Schofield (1973) found that illiteracy fell slightly between 1754 and 1844; cf. Mitch (1993).

${ }^{35}$ Voth (2001).
} 
We use two different price indices, the consumer price index compiled by Feinstein as well as Clark's GDP deflator. Feinstein's represents an important improvement over earlier series. The range of commodities covered is wider than in earlier studies (incorporating items such as milk, beer, potatoes and cheese), contains new information on the price of cotton cloth, and includes a national measure of rent. The new series implies markedly slower growth of real wages largely because prices fell less between 1801 and 1850 than Lindert and Williamson had assumed. ${ }^{36}$ For the purposes of productivity measurement, we would ideally want to use the GDP deflator, i.e. include the price of exports and exclude the price of imports. One such series has been compiled by Clark (2001b). As a check on our results, we will also correct explicitly for the bias arising from traded goods, using the Feinstein index as a basis for our estimate.

The series for land rental values is potentially more problematic. In contrast to recent studies of East Asia, we need to include land as a factor of production - the share of rents in total income was approximately $15 \% .{ }^{37}$ As for data on land rents, there are the alternative series by Turner, Beckett and Afton (1997) and by Clark. ${ }^{38}$ Since changes over time are broadly similar, the choice of index is not decisive. We will use the latter in our benchmark estimates and the former in our sensitivity tests.

A more difficult question is whether rents are a good indicator of the return to land. For our dual estimates of productivity growth to be accurate, factors need to be paid the value of their marginal product. Allen argues that since rents "were not adjusted annually and so could fall behind changes in land values, $[\ldots]$ price calculations can give spurious measures of productivity change". 39 Even if rents were adjusted slowly, as long as a more or less constant proportion of rents were changed each year, any increase in the value of land would lead, in the long run, to a proportional increase in rents. ${ }^{40}$ Since in

\footnotetext{
${ }^{36}$ Lindert and Williamson (1983).

${ }^{37}$ Deane and Cole argue that agricultural income was equivalent to $43 \%$ of national income (1962, p. 78$)$. Crafts (1985, p.16) considered this figure to be too high and proposed instead a share of $37 \%$. Of this, rent is only a fraction. Clark (2002) estimates a proportion of $40 \%$, which suggests a share of land (abstracting from urban rents) of $15 \%$. This is exactly the figure proposed by Crafts (1985).

${ }^{38}$ Clark (1998, 2002), Turner, Beckett and Afton (1997). Allen (1999, p. 23-25) argues that each has advantages and flaws.

${ }^{39}$ Allen (1994, p. 111).

${ }^{40}$ The situation is analogous to the response of prices to an exogenous increase in money supply in a macroeconomic model with staggered adjustment of individual prices. In this type of models, money is neutral in the long run and unless one introduces 'real rigidities', inflation is likely to catch with money growth quite fast. See Chapter 6 in Romer (1996) for an introduction to these models. A similar argument can be made for the impact of enclosure. Some scholars
} 
this paper we compute productivity growth over thirty-year periods, it is most likely that the growth rate of rents is not affected.

We estimate the rental cost of capital based on the standard Hall-Jorgenson formula. ${ }^{41}$ For this, we require information for three separate components - real interest rates, the relative price of capital, and depreciation rates:

$$
r=\frac{R}{P}=\frac{P_{k}}{P}(i-\pi+\delta)
$$

where $\mathrm{P}_{\mathrm{k}} / \mathrm{P}$ is the relative price of capital, $\mathrm{i}$ is the interest rate, $\pi$ is inflation, and $\delta$ is the depreciation rate. We use Feinstein's price series for capital goods, which includes dwellings, agricultural works, and for plant and machinery. ${ }^{42}$ For the depreciation rates, we calculate the average annual rates from the estimates of capital formation constructed by Feinstein and Pollard. ${ }^{43}$

A potentially more delicate question is the choice of interest rate. We would ideally like to use interest rates for private sector borrowing, such as the loan rate charged by country banks. Such information is presently not available. We use the yield on Consols instead. ${ }^{44}$ Three Percent Consols, the largest component of the British government's funded debt, paid a fixed nominal interest rate of 3\% and were perpetual yet - in principle - callable. Their price fluctuated in response to changes in the supply and demand of capital, inflation, and the perceived riskiness of government bonds. There is every reason to assume that private-sector borrowing was more expensive than that of the government. As long as the spread of private over public borrowing was relatively constant, however, we will still be able to infer trends over time from the yield on Consols.

The potentially most damaging problem could arise from the usury laws - English law imposed an upper limit on interest rates. In times of high government borrowing,

(Allen, 1992) have argued that rent increases did not signify greater land productivity, but simply showed a redistribution of income. Since such an effect should, in the medium to long term, be reflected in correspondingly slower wage growth, our results would not be affected.

${ }^{41}$ Hall and Jorgenson (1967). Our reasons for not using estimates of the capital/output ratio to calculate the rental rate are discussed in Antràs and Voth (2000). Note that equation (5) is not dependent on assumptions about the production function, but follows from maximizing the value of the firm's assets. Cf. the Appendix.

${ }^{42}$ Feinstein $(1978$, p. 38). We weight these according to their contribution to the total stock of domestic reproducible fixed assets (Feinstein and Pollard, 1988, Table XIV, p. 454).

${ }^{43}$ Feinstein and Pollard (1988, Table I, p. 427).

${ }^{44}$ Mitchell (1971, p. 455). 
such as during wartime, private investment might have been 'crowded out'. English wartime borrowing was high. At the time of Waterloo, Britain's public debt was valued at 2.3 times GDP. This would make the use of interest rates on Consols problematic - their yield would not only be lower than private sector borrowing rates, but the differential would vary substantially over time. Thus, the interest rate on Consols used may not just be artificially low, but may also mask very high rates of interest for private borrowing during wartime. ${ }^{45}$ Subsequent research, however, strongly suggests that this was not the case. ${ }^{46}$ Clark (2001a) shows that charities obtained yields on their assets that were broadly similar to the Consol yields. Also, the rates of return on mortgages by the Sun Life insurance are broadly similar to Consol yields and the charity returns. ${ }^{47}$ The Sun Fire Insurance, just like other insurance companies, invested some of its premium income in private debt. ${ }^{48}$ Mortgages tended to be relatively long-dated, often with maturities of 10 years or above. However, since the interest rate was subject to renegotiation, mortgage rates were not similar to long-term commercial interest rates. As Table 2 shows, the premium that could be earned from investing in mortgages was relatively small.

Table 2: Interest rates in England, 1750-1799

$3 \%$ Consols Charity returns $\quad \begin{aligned} & \text { Sun fire office } \\ & \text { mortgage rate }\end{aligned}$

\begin{tabular}{llll}
$\mathbf{1 7 5 0 - 5 9}$ & 3.40 & 4.31 & 4.30 \\
$\mathbf{1 7 6 0 - 6 9}$ & 3.60 & 4.53 & 4.70 \\
$\mathbf{1 7 7 0 - 7 9}$ & 3.74 & 4.65 & 4.10 \\
$\mathbf{1 7 8 0 - 8 9}$ & 4.65 & 4.68 & 4.85 \\
$\mathbf{1 7 9 0 - 9 9}$ & 4.54 & 4.82 & 4.65 \\
\hline
\end{tabular}

Sources: See text.

Movements over time in the rate of interest did not differ greatly, even if there is some divergence in the 1770s and 1780s. The correlation between Consol yields and the Sun rate of return is 0.64 ; between the Consols and the charity returns, it is 0.82 . This implies that Consols served as a benchmark for other long-term interest-bearing assets, offering a

\footnotetext{
${ }^{45}$ Williamson (1984).

${ }^{46}$ Cf. Mokyr (1987), Clark (2001a).

${ }^{47}$ John (1953). The rates are from the Sun Fire Insurance, Minutes of the General Meeting and Minutes of Quarterly Meetings.

${ }^{48}$ Mortgages constituted around 50\% of 'stock account' balances (Mirowski, 1981, p. 562).
} 
lower yield on account of the low perceived default risk. There is therefore little empirical evidence to suggest that the rate of return on private assets did not move in line with the yield on Consols. ${ }^{49}$

This conclusion is strengthened by the fact Consol rates acted as an important reference rate for a considerable part of economic activity. Public utility investment rose and fell in line with the yield on Consols, most notably in the case of turnpike construction. ${ }^{50}$ From 1770 onwards, London interest rates had a strong influence on the Yorkshire property market, and nationwide swings in bankruptcies also suggest a high degree of capital market integration. ${ }^{51}$ Consol rates also influenced the rate of enclosure. $^{52}$

Having discussed the methodological assumptions underlying the dual approach to productivity measurement as well as the data sources used, we now turn to the main results. Table 3 gives our preferred estimates of TFP growth during the Industrial Revolution, and compares them to the latest estimates offered by Crafts and Harley. ${ }^{53} \mathrm{We}$ follow Crafts (1985) in using factor shares of 0.5 for labour, 0.35 for capital, and 0.15 for land initially.

\footnotetext{
${ }^{49}$ Neal (1994, p. 156) calls the consol rate "the best barometer of the schedules of loanable funds".

${ }^{50}$ Presnell (1960).

${ }_{51}^{51}$ Buchinsky and Polak (1993), Hoppit (1986).

${ }^{52}$ McCloskey (1994, p. 254).

${ }^{53}$ Note that, since the new Feinstein wage series is only available from the 1770s onwards, we can only present estimates from this data onwards.
} 
Table 3: Estimates of Productivity Growth in England, 1770-1860

\begin{tabular}{|c|c|c|c|c|c|}
\hline $\begin{array}{r}\text { annual percentage } \\
\text { rate of change }\end{array}$ & $\mathbf{r}$ & $\mathbf{W}$ & $\mathbf{q}$ & & TFP \\
\hline \multicolumn{6}{|l|}{ Benchmark Estimate 1} \\
\hline $1770-1800$ & -0.39 & 0.40 & 0.27 & & 0.10 \\
\hline $1800-1830$ & 0.82 & 0.34 & 0.87 & & 0.59 \\
\hline $1830-1860$ & -0.33 & 0.56 & 0.36 & & 0.22 \\
\hline $1770-1830$ & 0.22 & 0.37 & 0.57 & & 0.35 \\
\hline Benchmark Estimate 2 & & & & tot & \\
\hline $1800-1830$ & 0.82 & 0.34 & 0.87 & -1.22 & 0.71 \\
\hline $1830-1860$ & -0.33 & 0.56 & 0.36 & -1.61 & 0.44 \\
\hline Preferred Estimate & & & & gov & \\
\hline $1770-1800$ & -0.40 & 0.35 & 0.26 & 2.60 & 0.27 \\
\hline $1800-1830$ & 0.71 & 0.25 & 0.76 & 1.11 & 0.54 \\
\hline $1830-1860$ & -0.21 & 0.68 & 0.48 & 0.31 & 0.33 \\
\hline \multirow[t]{2}{*}{$1770-1830$} & 0.15 & 0.30 & 0.51 & 1.85 & 0.41 \\
\hline & $\mathbf{Y}$ & $\mathbf{K}$ & $\mathbf{L}$ & $\mathbf{T}$ & \\
\hline \multicolumn{6}{|l|}{ Crafts/Harley (1992) } \\
\hline $1760-1801$ & 1 & 1 & 0.8 & - & 0.1 \\
\hline $1801-1831$ & 1.9 & 1.7 & 1.4 & - & 0.35 \\
\hline $1760-1831$ & 1.45 & 1.35 & 1.1 & & 0.22 \\
\hline \multicolumn{6}{|l|}{$\begin{array}{l}\text { Crafts/Harley (1992)- } \\
\text { three-factors* }\end{array}$} \\
\hline $1760-1800$ & 1 & 1 & 0.8 & 0.2 & 0.19 \\
\hline $1801-1831$ & 1.9 & 1.7 & 1.4 & 0.4 & 0.50 \\
\hline $1831-1860$ & 2.5 & 2.0 & 1.4 & 0.6 & 1.00 \\
\hline $1760-1831$ & 1.45 & 1.35 & 1.1 & 0.3 & 0.34 \\
\hline
\end{tabular}

Sources: $\quad$ See text. Crafts and Harley (1992).

* as recalculated by Harley (1999b, p. 183).

Notes: $\quad$ Benchmark estimate 1 does not correct for changes in the terms of trade or indirect taxes, and uses the Feinstein price index.

Benchmark estimate 2 uses the Feinstein price index, and adjusts for terms of trade effects as discussed in the text.

Preferred estimate uses the GDP deflator by Clark (2001b), and adds changes in indirect taxes.

tot is the change in the terms of trade, based on Imlah (1958).

gov is the growth in indirect taxes, based on Mitchell (1971, pp. 386-393).

When we use the Feinstein price series in our benchmark 1 estimate, the rental cost of capital is falling for the first period 1770-1801. Combined with slow growth in real wages and rents, this implies very slow TFP growth. To avoid the influence of volatile 
year-to-year variations in prices, we use decade averages. The best standard of comparison is the latest set of estimates from Crafts and Harley, which we adapt to a three-factor model. ${ }^{54}$ The last estimate in Table 3 gives the figures for such an approach. The baseline Crafts-Harley estimate becomes 0.19\% p.a. for 1760-1801 and 0.5\% p.a. for 1801-31. These figures are marginally higher than the original Crafts-Harley figures, largely as a result of the lower weight on capital. ${ }^{55}$ Benchmark 1 yields an estimate for the first period that is $0.09 \%$ lower and an estimate for the second period that is $0.09 \%$ higher.

Overall, our benchmark 1 estimates for the first 60 years of the Industrial Revolution agree almost exactly with those favoured by Crafts and Harley. Our estimates of price changes would have to be wrong by several orders of magnitudes to restore the most 'optimistic' estimates in the TFP literature. ${ }^{56}$ For the period 1831-60, we find positive TFP growth, just as Crafts (1985) argued, if at a markedly lower level.

We believe that the Feinstein (1998a) price series is superior to the alternatives. The use of a GDP deflator would, however, be conceptually more appropriate. The consumption price index contains imported goods, and fails to fully incorporate all goods exported. Since it is the productivity of the British economy that we are trying to measure, the GDP deflator is the conceptually correct price series. Also, the weights in the Feinstein reflect the basket of goods purchased by working class households, not economic output as a whole. Two procedures can address this problem. We can use either an explicit correction for terms-of-trade effects to overcome the first issue, or we can use existing estimates for the GDP deflator, and sidestep both conceptual problems.

Sharp deteriorations of the terms of trade will lead us to underestimate true productivity growth, since the decline in the external value of Britain's products - and not the rate of productivity growth alone - is partly responsible for the slow rise in the combined value of all factors of production. To incorporate changes in terms of trade, we

\footnotetext{
${ }^{54} \mathrm{Cf}$. Antràs and Voth (2000) for details.

${ }^{55}$ For the first period, $100 \%$ of the revision is a result of assigning a greater weight to capital (capital grows at $1 \%$ p.a., land at $0.2 \%$ p.a.; increasing the weight on capital from 0.35 to 0.5 reduces the TFP measure). In the second period, growth would be $0.15 \%$ p.a. more rapid if Crafts's original three-factor approach had been pursued $(\mathrm{TFP}=0.5 \%$ p.a. instead of $0.35 \%$ ).

${ }^{56}$ Those by Feinstein (1981). Converting his figures to our three-factor approach, using the factor shares of $0.5,0.35$, and 0.15 for labour, capital and land, respectively, as well as the estimates of land in use from Crafts (1985), suggests TFP growth of 0.3 and 1.45 for $1760-1801$ and 1801-1831.
} 
apply an adjustment to our estimates. In an open-economy, the CPI will be a weighted geometric average of the price of domestic goods $\left(\mathrm{P}_{\mathrm{N}}\right)$ and the price of imports $\left(\mathrm{P}_{\mathrm{M}}\right)$, while the GDP deflator is a weighted average of the price of non-traded goods and the price of exports $\left(\mathrm{P}_{\mathrm{X}}\right)$. If the shares of non-tradables in consumption and in production are identical, we have:

$$
\tau=\frac{C P I}{P}=\frac{P_{N}{ }^{\alpha} P_{M}{ }^{1-\alpha}}{P_{N}{ }^{\alpha} P_{X}{ }^{1-\alpha}}=\left(\frac{P_{M}}{P_{X}}\right)^{1-\alpha}=\Gamma^{-(1-\alpha)}
$$

where $\Gamma$ are the terms of trade, CPI is the Feinstein index from our benchmark 1 estimate, whereas $\mathrm{P}$ is the GDP deflator we should ideally use. We thus obtain $\hat{\tau}=-(1-\alpha) \hat{\Gamma}$ where $\alpha$ is the share of exports in national product. To adjust the productivity calculation for changes in the terms of trade, we have to add a correction to the original figure. The accouting equation becomes $\quad T F P_{\text {Dual }}=\hat{Y}-\eta_{K} \hat{K}-\eta_{L} \hat{L}-\eta_{T} \hat{T}=\eta_{K} \hat{r}+\eta_{L} \hat{w}+\eta_{T} \hat{q}+\hat{\tau}$. Reasonable figures for the terms of trade are available from $1800 .{ }^{57}$ Based on these, we find that 0.12 and $0.22 \%$ p.a. should be added to the second and third period (benchmark 2 estimate). ${ }^{58}$ These do increase our estimates of TFP growth, but they remain relatively low overall. We should note that, since trade statistics are for Great Britain, we do not capture the decline in the terms of trade for intra-British transactions. Since England effectively traded manufactured goods for food from Ireland, our figures probably understate the true effect of the decline in the terms of trade somewhat.

An alternative is the GDP deflator presented by Clark (2001b). This should already incorporate the effects of changes in the terms of trade. Using it suggests a marginally sharper reduction in the returns to capital in the first thirty years. For the period 1770-1830 as a whole, returns to labor, capital and land appear a little lower than in the figures for benchmark 1. We should arguably also include indirect taxes. These increased rapidly over the period - especially in the final decades of the 18th century. This constitutes an additional claim on output (which would have accrued to another factor of production if it had not been taxed), and should thus enter in our calculation with the average share of indirect taxes in national income. Since indirect taxes grew by $2.6 \%$ p.a. over the first thirty years, a share in national income of $8 \%$ suggests a

${ }^{57}$ Crafts (1985, table 7.5, p. 147), based on Imlah (1958). 
correction of $+0.21 \%{ }^{59}$ During the second and third period, the changes are smaller $(+0.09 \%$ and $0.02 \%)$. The pattern of relatively slow initial productivity growth, followed by a mild acceleration after the end of the Napoleonic wars, remains unchanged. Without the correction for indirect taxes, productivity growth is $0.28 \%$ p.a. over the period 1770 1830 , only marginally lower than the $0.35 \%$ we find when using the Feinstein consumer price index. Including the claims of the government suggests total factor productivity growth of $0.41 \%$. This final figure represents our preferred estimate. While not identical with the Crafts-Harley results, these estimates are very similar in overall magnitude. What divergence there is from their figures is a result of including the government sector and terms-of-trade effects. In terms of economic implications, our findings confirm that productivity growth was not fast during the first sixty years of the Industrial Revolution even if we incorporate the sharp decline in the terms of trade and the increasing claims of the government sector.

Our findings are also broadly consistent with those of Clark (2001b), who performs a similar calculation, using factor prices. He finds productivity growth of $0.2 \%$ for the first thirty years, $1.0 \%$ for the year $1800-1830$, and $0.22 \%$ for $1830-1860$. The magnitudes are similar, even if the acceleration after 1800 is sharper than in our figures. Our estimates for the slowdown after 1830 are broadly similar, questioning the acceleration found by Crafts and Harley - and lending further weight to the slow growth argument overall. Differences between Clark's and our results are mainly driven by his use of an alternative wage series and cost of capital calculations that do not employ the Hall-Jorgenson formula. ${ }^{60}$

Using 1800 as a benchmark date is common in most growth accounting exercises. It is more problematic in the case of dual productivity estimates, as the very high prices of the Napoleonic period may have skewed factor incomes. In particular, it could be argued that our measures of the return on capital and land are biased downwards, at a time when their shares of income actually increased. The problem is already mitigated since we use decade averages, i.e. our figures for TFP growth 1771 to 1801 really

\footnotetext{
${ }^{58}$ We use the weights from Irwin (1991, p. 98).

${ }^{59}$ We reduced the share of labour by 5 , capital by 2 , and of land by 1 percent in the production function. The weight of 8 percent comes from Clark (2001b).

${ }^{60}$ Clark performs no sensitivity analysis and only uses his own data series in compiling his estimates.
} 
compare data from 1771-1780 with 1801-1810. The longer the period under consideration, the less volatile short-term price movements matter. We also present the results for 1770-1830 for the preferred estimate and the benchmark 1 estimate. They suggest growth of 0.41 and 0.35 , respectively - somewhat higher than the 0.34 calculated by Crafts and Harley, but hardly a significant upward revision.

\section{Sensitivity tests}

We have already emphasized that the quality of the underlying data and the difficulties in fixing appropriate weights in aggregating the series allow us to construct no more than 'controlled conjectures' (Feinstein, 1996). How sensitive are our results? Here, we analyse the impact of using (i) different factor shares (ii) alternative series for the rental cost of agricultural land, (iii) different measures of the cost of capital, and (iv) another price series. $^{61}$

Crafts and Harley (1992) only use capital and labour for the TFP calculations, assigning an elasticity of 0.5 to each. We take the government sector (with an expenditure share in GDP of $8 \%$ ) into account, setting $\eta_{L}=\eta_{K}=0.42$ and $\eta_{\text {Gov }}=0.08$. This generates our alternative estimate 2. A reasonable upper bound on the factor share assigned to labour is 0.6 to $0.7 .^{62}$ We use a share of 0.64 for labour, 0.19 for capital and 0.09 for rents to derive alternative estimate 3 . Table 4 compares the results with our preferred estimate (column 1).

Table 4: Sensitivity tests - alternative factor shares

\begin{tabular}{cccc}
\hline estimate & 1 & 2 & 3 \\
\cline { 2 - 4 }$\eta_{\mathrm{K}}$ & 0.33 & 0.46 & 0.19 \\
$\eta_{\mathrm{L}}$ & 0.45 & 0.46 & 0.64 \\
$\eta_{\mathrm{T}}$ & 0.14 & - & 0.09 \\
$\eta_{\text {Gov }} \mathrm{TFP}$ & 0.08 & 0.08 & 0.08 \\
$1770-1800$ & & & \\
$1800-1830$ & $0.27 \%$ & $0.18 \%$ & $0.38 \%$ \\
$1830-1860$ & $0.54 \%$ & $0.53 \%$ & $0.45 \%$ \\
\hline
\end{tabular}

\footnotetext{
${ }^{61}$ Note that introducing rational expectations does not materially affect our cost of capital computations (see Appendix).

${ }^{62}$ Nelson (1964) assumes that the likely upper bound is $\eta_{L}=0.75$ for the US in the twentieth century. This almost certainly includes a large component for human capital (cf. Mankiw, Romer and Weil, 1992).
} 
Changing the weights only has a marginal impact on our estimates. TFP growth for 17711800 falls to $0.18 \%$ if we disregard land as a factor of production. Just as in the results of Crafts and Harley, excluding land as a factor of production results in lower productivity growth. TFP growth after 1831 is almost identical with our preferred estimate. The alternative estimate (3) shows marginally larger divergence, suggesting a TFP growth rate for $1771-1800$ that is $0.11 \%$ higher. For the second period, the range of alternative results is never higher than $0.54 \%$ p.a. Even the most 'optimistic' of these estimates is still considerably below the level of $1.3 \%$ originally calculated by Feinstein. The range of possible estimates therefore remains too low to lend credence to the rates implied by Cuenca Esteban or Berg and Hudson. 
Table 5: Sensitivity tests - alternative rent, cost of capital, and price indices

\begin{tabular}{|c|c|c|c|c|c|c|c|}
\hline estimate & & $\begin{array}{l}\text { percentage } \\
\text { rate of change }\end{array}$ & $\mathbf{R}$ & $\mathbf{W}$ & $\mathbf{q}$ & gov & TFP \\
\hline \multicolumn{8}{|c|}{ preferred estimate } \\
\hline & 1 & $1770-1800$ & -0.40 & 0.35 & 0.26 & 2.60 & 0.27 \\
\hline & & $1800-1830$ & 0.71 & 0.25 & 0.76 & 1.11 & 0.54 \\
\hline & & $1830-1860$ & -0.21 & 0.68 & 0.48 & 0.31 & 0.33 \\
\hline & & 1770-1830 & 0.15 & 0.30 & 0.51 & 1.85 & 0.41 \\
\hline \multicolumn{8}{|c|}{$\begin{array}{l}\text { Turner, Beckett and } \\
\text { Afton rents }\end{array}$} \\
\hline & 2 & $1770-1800$ & -0.40 & 0.35 & 0.30 & 2.60 & 0.28 \\
\hline & & $1800-1830$ & 0.71 & 0.25 & 1.68 & 1.11 & 0.67 \\
\hline & & $1830-1860$ & -0.21 & 0.68 & 0.56 & 0.31 & 0.34 \\
\hline & & 1770-1830 & 0.15 & 0.30 & 0.99 & 1.85 & 0.47 \\
\hline \multicolumn{8}{|c|}{ Clark real rents } \\
\hline & 3 & $1770-1800$ & -0.40 & 0.35 & 0.11 & 2.60 & 0.25 \\
\hline & & $1800-1830$ & 0.71 & 0.25 & 1.10 & 1.11 & 0.59 \\
\hline & & $1830-1860$ & -0.21 & 0.68 & 0.37 & 0.31 & 0.31 \\
\hline & & 1770-1830 & 0.15 & 0.30 & 0.61 & 1.85 & 0.42 \\
\hline \multicolumn{8}{|c|}{ Clark charity returns } \\
\hline & 4 & $1770-1800$ & -1.48 & 0.35 & 0.26 & 2.60 & -0.09 \\
\hline & & $1800-1830$ & 0.51 & 0.25 & 0.76 & 1.11 & 0.48 \\
\hline & & $1830-1860$ & -0.23 & 0.68 & 0.48 & 0.31 & 0.32 \\
\hline & & 1770-1830 & -0.48 & 0.30 & 0.51 & 1.85 & 0.20 \\
\hline \multicolumn{8}{|c|}{$\begin{array}{l}\text { Lindert-Williamson } \\
\text { price index }\end{array}$} \\
\hline & 5 & $1780-1800$ & 1.00 & 0.11 & 0.41 & 2.56 & 0.64 \\
\hline & & $1800-1830$ & -0.24 & 0.79 & 1.33 & 1.67 & 0.60 \\
\hline & & $1830-1860$ & 2.32 & 0.67 & 0.33 & 0.44 & 1.15 \\
\hline & & 1780-1830 & 0.26 & 0.52 & 0.96 & 2.03 & 0.61 \\
\hline \multicolumn{8}{|c|}{ wholesale price index } \\
\hline & 6 & $1770-1800$ & -0.35 & 0.43 & 0.31 & 2.65 & 0.33 \\
\hline & & $1800-1830$ & 1.44 & 0.95 & 1.49 & 1.83 & 1.26 \\
\hline & & 1770-1830 & 0.54 & 0.69 & 0.90 & 2.24 & 0.80 \\
\hline
\end{tabular}

In our preferred estimates, we use the nominal rental cost of land, as calculated by Clark, which we deflate by the price series in Clark (2001b). Two main alternatives suggest themselves, as argued in our data section. The first is to use the rental series provided by Turner, Beckett and Afton $(1997,1998) .{ }^{63}$ Table 5, estimate 2 shows the impact. The upward revision for the first period is small indeed, a mere $0.01 \%$ p.a. - clearly no more than any sensible estimate of the likely margin of error. The difference for the second

${ }^{63}$ Allen (1999) argues that these estimates are superior. 
period is somewhat larger, adding $0.13 \%$ p.a. to the preferred estimate. This figure is now relatively high; the average for the period 1770-1830, which is much less affected by short-term price movements, only changes from 0.41 to 0.47 .

We could also have used the real rent series provided by Clark. He deflates the rental series by the price of 11 farm commodities. ${ }^{64}$ By using the price of agricultural products instead of a general price index, we would generate a measure of what part of national income accrued to land in terms of its own product. While deflating by output prices in this fashion is undoubtedly correct when trying to calculate the productivity of agriculture (based on a dual approach), it is probably less sensible for the economy as a whole. As we are trying to assess productivity change in the aggregate, we need to derive a general measure of the increase of product accruing to factors of production in terms of all outputs. Estimate 3 gives the results using his real rental cost of land series. TFP growth during the first period is even slower than in our preferred estimate. Growth after 1801 is somewhat more rapid. The two main findings - very slow growth during the initial decades, combined with a moderate acceleration after 1800 - are not overturned by using either the Turner, Beckett and Afton series or the Clark real rent series. For the period 1770-1830 as a whole, we do not find TFP growth approaching even one percent per year.

Our cost of capital series, based on Consol yields, is arguably less robust than other data sources. We use yield on Charity assets as a plausibility check. Estimate 4 gives the results based on the return series from Clark (2001a). We use the average rent charges backed by the assets of a corporation, by land or a house, as well as the mortgage rates for turnpike tolls and land. ${ }^{65}$ The swings in the cost of capital become more extreme, largely as a result of very low (real) returns during the first decade of the nineteenth century. This initially leads to negative TFP estimates for the period 17701800. The recovery from this depressed level drives up the rate of TFP growth after 1801. While the point estimates differ from those of our preferred estimate, the broad pattern of initially slow growth, followed by an acceleration after 1800 , is also clearly visible. The

\footnotetext{
${ }^{64}$ Clark (2002), appendix.

${ }^{65}$ The data is available at http://www.econ.ucdavis.edu/faculty/gclark/papers/CCRET99.txt
} 
average for the period $1770-1830$ as a whole is $0.21 \%$ lower than in our preferred estimate. $^{66}$

The Feinstein price series is relatively pessimistic. To derive an upper bound for our productivity calculations, we also use the Lindert and Williamson price series (estimate 5). ${ }^{67}$ This leads to higher TFP growth, as is to be expected. Compared to our preferred estimate, the Lindert and Williamson series results in an upward revision of 0.37 for the first period (where we have to compare 1770-1800 with 1780-1800 because of data availability), an increase of 0.06 for the second period, and 0.82 for the third. Of these differences, the final one is clearly an overestimate. All the corrections in the Feinstein series that reduce the price decline between 1830 and 1850 are sensible improvements, and not a matter of opinion -- including the use of a wider set of goods consumed, adding a better rent series, and updating consumption shares. ${ }^{68}$ For the earlier ones, we note that the Lindert-Williamson series does not in fact consistently lead to the most optimistic estimates - both the Turner, Beckett and Afton rents and the wholesale price index by Feinstein (see below) produce higher estimates for 1800-1830. Overall, for the years 1780-1830, the Lindert-Williamson series only gives an upward revision of 0.20 percent per year.

One final alternative is the use of another price series (estimate 6). Feinstein (1978) compiled an index of wholesale prices. Using his series, we find marginally higher factor productivity growth for the first thirty years, and then a more substantial acceleration - a result of wholesale prices surging more in the inflationary period up to 1800 , and then declining more rapidly than other price indices. For the first sixty years as a whole, the wholesale index suggests TFP growth of 0.80 instead of the 0.41 in our preferred estimate.

\footnotetext{
$\overline{{ }^{66} \text { We also experimented with stock }}$ market returns. These are not very appropriate in methodological terms since so few firms were listed, but they yield broadly similar results (Antràs and Voth, 2000).

${ }^{67}$ Lindert and Williamson (1985). The nominal wage series agree almost completely; the price series accounts for the difference between optimism and pessimism.

${ }^{68}$ Feinstein (1998a, table 3, p. 641). Note that Clark calculates a price series for agricultural labourers that tends to move between the Lindert-Williamson and the Feinstein series. This, however, largely reflects the peculiarities of their consumption bundle.
} 
Overall, the sensitivity checks do not suggest that our estimates are particularly fragile. ${ }^{69}$ Two crucial elements of the Crafts-Harley view are vindicated. First, independent of the indices for capital cost, rental cost, or overall prices used, we find that productivity growth was very slow during the last three decades of the eighteenth century. If anything, alternative data sources suggest even lower rates of productivity change, especially for the first thirty years. This, it could be argued, is not as implausible as it might appear at first glance. These low TFP figures are in the same range as Voth's recent estimates, who revised labour input figures upwards. Thus, even our most pessimistic estimates are compatible with primal productivity calculations. ${ }^{70}$ Second, we find an acceleration to more rapid but still moderate rates of TFP growth during the period 1801-1831. Here, all our alternative estimates - with one exception - suggest rates at or slightly above the $0.5 \%$ p.a. argued for by Crafts and Harley.

Table 6: Counterfactual factor price ratios

\begin{tabular}{lcccccc}
\hline \multirow{2}{*}{ preferred } & & $\mathbf{r}_{\mathbf{t}+\mathbf{1}} / \mathbf{r}_{\mathbf{t}}$ & $\mathbf{w}_{\mathbf{t}+\mathbf{1}} / \mathbf{w}_{\mathbf{t}}$ & $\mathbf{q}_{\mathbf{t}+\mathbf{1}} / \mathbf{q}_{\mathbf{t}}$ & $\mathbf{g o v}_{\mathbf{t}+\mathbf{1}} / \mathbf{g o v}_{\mathbf{t}}$ & $\mathbf{T F P}$ \\
\cline { 3 - 7 } & $1800 \mathrm{~s} / 1770 \mathrm{~s}$ & 0.89 & 1.11 & 1.08 & 2.18 & 1.08 \\
counterfactual & $1830 \mathrm{~s} / 1800 \mathrm{~s}$ & 1.24 & 1.08 & 1.26 & 1.39 & 1.18 \\
& & & & & & \\
& $1830 \mathrm{~s} / 1770 \mathrm{~s} / 1800 \mathrm{~s}$ & 1.49 & 1.11 & 1.49 & 2.18 & 1.35 \\
difference & $1800 \mathrm{~s} / 1770 \mathrm{~s}$ & 0.60 & 1.08 & 2.27 & 1.39 & 1.56 \\
& $1830 \mathrm{~s} / 1800 \mathrm{~s}$ & 1.03 & 0.00 & 0.41 & 0.00 & 0.26 \\
\hline
\end{tabular}

One further way of examining the robustness of our findings is to ask how high factor price increases would have to be in order to restore the 'fast growth' hypothesis. Table 6 offers such a calculation. We believe that it is highly unlikely that a convincing case for revising real wages substantially upwards will be made. Also, indirect taxes appear to be increasing as fast as can sensibly be argued for the period. Therefore, higher productivity growth estimates would have to be the result of faster growth in the rental rate of capital and land. For ease of presentation, we assume $\mathrm{q}_{\mathrm{t}+1} / \mathrm{q}_{\mathrm{t}}=\mathrm{r}_{\mathrm{t}+1} / \mathrm{r}_{\mathrm{t}}$. Also, we believe that the lowest possible rates of productivity growth needed to restore the view that growth was

\footnotetext{
${ }^{69}$ We derived likely margins of error, based on a method recently extended by Feinstein and Thomas (2000). The error bands are never small. Nonetheless, rapid productivity growth can be ruled out. Cf. Antràs and Voth (2000) for details. A similar conclusion applies when we introduce rational expectations; cf. Appendix.

${ }^{70}$ Voth $(1998,2001)$.
} 
relatively 'fast' are 1\% p.a. 1771-1801 and 1.5\% p.a. 1801-31. By historical standards e.g. the post-war boom in OECD countries etc. - these would still be very low. To raise annual productivity growth sufficiently, TFP in 1800 relative to 1770 would have to be $35 \%$ higher - whereas the actual increase, according to our calculations, is $8 \%$. For the second period, we measure a change of $17.7 \%$; growth of $1.5 \%$ per annum requires an overall rise in TFP in 1830 relative to 1800 of $56 \%$.

The counterfactual estimate in Table 6 shows how large the increases in factor costs would have to be to produce such a revision. The rental cost of land would have to increase by 49 and 127\%, whereas actual change was +8 and $26 \%$; in the case of capital, returns would have had to rise by 60 and $103 \%$ more than they actually did to restore the fast growth view. The differences from our preferred estimates are very large. Also, even the most optimistic estimates derived from alternative data sources or using altered assumptions are insufficient to yield TFP growth rates on this order of magnitude. Another calculation shows how improbable the implications of significant TFP growth as reflected in factor prices - are. If one were to argue that capital income was indeed significantly underestimated, and that the true change in the rental was closer to the values in Table 6 , then the capital share in national income would have had to increase to 2.8 times its 1770 level by 1830 - a change so large that it can easily be ruled out. While the fragility of the data must be emphasized, it is hard to see how the evidence from dual productivity estimates could be reconciled with the view that productivity change during Britain's industrial revolution was relatively rapid.

\section{Conclusions}

Critics of productivity and growth estimates during the industrial revolution often imply that the Crafts-Harley view, and the quantity-based calculations on which it is based, is little more than a house of cards. In particular, some scholars have argued that output and productivity growth during the English industrial revolution must have been more rapid than the current orthodoxy has claimed. ${ }^{71}$

\footnotetext{
${ }^{71}$ Berg and Hudson (1992), Cuenca Esteban (1994).
} 
This paper shows that independent evidence, using an alternative method, yields results that are very similar to the Crafts-Harley view. We base our productivity calculations on factor prices, and thereby offer confirmation of the main findings by Crafts and Harley from a new and independent source. The quality of our estimates can only be as high as our sources allow. Yet, as Feinstein reminds us: ${ }^{72}$

"The case for quantification in the face of the multitude of gaps and uncertainties in the available data is not that it provides definitive estimates. It is, rather, that it helps to establish orders of magnitude, and to test how robust or vulnerable the estimates are to different assumptions and judgements the statistician is forced to make in the face of a lack of satisfactory evidence."

It is in this spirit that our results need to be interpreted. Productivity growth was very slow during the last decades of the eighteenth century, and may even have been zero. This is compatible with the Crafts-Harley view, and reinforces recent findings that further downward revisions of primal TFP calculations due to higher labour input may well be in order. ${ }^{73}$ There was no 'take-off' in the sense of Rostow. What acceleration there was occurred after 1800 , and was mild. The efficiency with which the economy combined factors of production never increased at a rate markedly faster than 0.5 per cent before 1830 , and probably much less than that.

How can the evidence in favour of slow productivity growth be squared with the data on foreign trade? Since Temin finds strong evidence that Britain became an exporter of all manufactured goods, he argues that productivity growth must have been relatively widespread. This would also suggest that aggregate growth rates have been underestimated. One of the central underlying assumptions in the Ricardian model of trade as used by Temin is that the relative price of factors of production does not change, and that wages are a good proxy for the overall cost of manufacturing. Our data on the remuneration of factors directly sheds light on this question. We find that the rental price of capital fell while wages rose in the first period; in the second, rental growth outpaced wage increases. The data used in the calculation of our dual productivity estimates therefore also demonstrate why the foreign trade data in itself - interpreted in Ricardian framework - is not necessarily at variance with the Crafts-Harley view of the industrial

\footnotetext{
${ }^{72}$ Feinstein (1996).

${ }^{73}$ Voth (1998, 2001).
} 
revolution. Britain may have manufactured a wide range of goods because factors of production other than labour were relatively cheap.

The dual approach also highlights the close connection between productivity growth on the one hand and the course of living standards on the other. Some scholars appear comfortable with a relatively pessimistic view of changes in living standards, while at the same time arguing that productivity growth has been understated (and is an insufficient measure of the speed of change). ${ }^{74}$ These are contradictory positions, as dual measurement of productivity growth makes clear. Unless the labour share in national income moved very sharply - for which there appears to be no reliable evidence - real wage growth in the long run has to follow the trend rate of TFP increases. ${ }^{75}$ Our dual estimates of productivity growth during the Industrial Revolution do not provide definitive estimates that could supersede the existing ones, based on primary TFP measures. Rather, they are useful because they add independent support using an altogether different method to the Crafts-Harley view. Even a house of cards can be remarkably stable if numerous independent elements support each other.

\footnotetext{
${ }^{74}$ Cf. Berg and Hudson (1992, p. 32-7).

75 Feinstein (1988). Note however that recent work has argued that the capital share may well have moved up (Feinstein, 1998b).
} 


\section{REFERENCES}

Allen, R. (1992), Enclosure and the Yeoman. Oxford.

Allen, R. (1994), “Agriculture during the Industrial Revolution." In R. Floud and D. N. McCloskey (Eds.), The Economic History of Britain since 1700, vol. 1. Cambridge, $2^{\text {nd }}$ edition. Pp. 96-122.

Allen, R. (1999), "Tracking the Agricultural Revolution." Economic History Review 52, 209-235.

Antràs, P., and Voth, H. -J. (2000), "Productivity Growth during the English Industrial Revolution.” UPF Economics Department working paper 495.

Ashton, T. S. (1948), The Industrial Revolution, 1760-1830. London.

Barro, R. J., and Sala-i-Martin, X. (1990), "World Real Interest Rates.” In O. Blanchard and S. Fischer (Eds.), NBER Macroeconomics Annual 1990. Cambridge, MA. Pp. 1561.

Berg, M., and Hudson, P. (1992), "Rehabilitating the Industrial Revolution." Economic History Review 45, 24-50.

Boskin, M., Dulberger, E., Gordon, R., Griliches, Z., and Jorgenson, D. (1998), "Consumer Prices, the Consumer Price Index, and the Cost of Living." Journal of Economic Perspectives 12, 3-26.

Buchinsky, M., and Polak, B. (1993), "The Emergence of a National Capital Market in England, 1710-1880." Journal of Economic History 53, 1-24.

Cecchetti, S. (1992), "Prices during the Great Depression: Was the Deflation of 19301932 Really Unanticipated?" American Economic Review 82, 141-156.

Clark, G. (1998), "Renting the Revolution.” Journal of Economic History 58, 206-10.

Clark, G. (1999), "Too Much Revolution: Agriculture in the Industrial Revolution, 17001860." In J. Mokyr (Ed.), The British Industrial Revolution: An Economic Perspective. Boulder, Colorado, $2^{\text {nd }}$ edition. Pp. 206-240.

Clark, G. (2001a), "Debts, Deficits, and Crowding-Out: England 1727-1840." European Review of Economic History 5 (3), 1-35.

Clark, G. (2001b), "The Secret History of the Industrial Revolution." Manuscript, University of California, Davis. Available at http://www.econ.ucdavis.edu/ gclark/.

Clark, G. (2002), "Farmland Rental Values and Agrarian History: England and Wales, 1500-1912." European Review of Economic History, forthcoming.

Collins, W., and Williamson, J. G. (2001), "Capital Goods Prices and Investment: 18701950." Journal of Economic History 61, 59-94.

Crafts, N. F. R. (1985), British Economic Growth during the Industrial Revolution. Oxford.

Crafts, N. F. R., and Harley, C. K. (1992), "Output Growth and the British Industrial Revolution: A Restatement of the Crafts-Harley View." Economic History Review 45, 703-730.

Crafts, N. F. R., and Harley, C. K. (2000), "Simulating the Two Views of the British Industrial Revolution.” Journal of Economic History 60, 819-842.

Cuenca Esteban, J. (1994), "British Textile Prices, 1770-1831: Are British Growth Rates Worth Revising Once Again?” Economic History Review 47, 66-105. 
Cuenca Esteban, J. (1995), "Further Evidence of Falling Prices of Cotton Cloth." Economic History Review 48, 145-150.

David, P. A. (1990), "The Dynamo and the Computer: An Historical Perspective on the Modern Productivity Paradox." American Economic Review 80, 355-361.

Deane, P., and Cole, W. A. (1962), British Economic Growth, 1688-1959. Cambridge.

Feinstein, C. H. (1978), "Capital Formation in Great Britain." In P. Mathias and M. Postan (Eds.), The Cambridge Economic History of Europe, vol. 7. Pp. 28-96.

Feinstein, C. H. (1981), "Capital Accumulation and the Industrial Revolution." In R. Floud and D. N. McCloskey (Eds.), The Economic History of Britain since 1700, vol. 1. Cambridge, $1^{\text {st }}$ edition. Pp. 128-142.

Feinstein, C. H. (1988), "The Rise and Fall of the Williamson Curve." Journal of Economic History 48, 699-729.

Feinstein, C. H. (1996), "Conjectures and Contrivances: Economic Growth and the Standard of Living in Britain During the Industrial Revolution." Oxford Economic History Working Paper 9.

Feinstein, C. H. (1998a), "Pessimism Perpetuated: Real Wages and the Standard of Living in Britain during and after the Industrial Revolution." Journal of Economic History 58, 625-658.

Feinstein, C. H. (1998b), "Wage-earnings in Great Britain during the Industrial Revolution.” In I. Begg and S. G. B. Henry (Eds.), Applied Economics and Public Policy. Cambridge. Pp. 181-208.

Feinstein, C. H., and Pollard, S. (1988), Studies in Capital Formation in the United Kingdom, 1750-1920. Oxford.

Feinstein, C. H., and Thomas, M. (2000), "A Plea for Errors." Unpublished manuscript, All Souls College, Oxford.

Griliches, Z., and Jorgenson, D. (1967), "The Explanation of Productivity Change." Review of Economic Studies 34, 249-283.

Hall, R., and Jorgenson, D. (1967), "Tax Policy and Investment Behaviour." American Economic Review 57, 391- 414.

Harley, C. K. (1982), "British Industrialization Before 1841: Evidence of Slower Growth during the Industrial Revolution." Journal of Economic History 42, 267-289.

Harley, C. K. (1999a), "Cotton Textile Prices Revisited: A Response to Cuenca Esteban." Economic History Review 52, 756-765.

Harley, C. K. (1999b), "Reassessing the Industrial Revolution.” In J. Mokyr (Ed.), The British Industrial Revolution: An Economic Perspective. Boulder, Colorado, $2^{\text {nd }}$ edition. Pp. 160-205.

Harley, C. K., and Crafts, N. F. R. (1995), "Cotton Textiles and Industrial Output Growth During the Industrial Revolution." Economic History Review 48, 134-144.

Hoffmann, W. G. (1955), British Industry 1700-1950. Oxford.

Honeyman, K. (1996), "Review of Periodical Literature. 1700-1850." Economic History Review 49, 170-177.

Hoppit, J. (1986), "Financial Crises in Eighteenth Century England." Economic History Review 39, 39-58.

Hoppit, J. (1990), "Counting the Industrial Revolution." Economic History Review 43, 174-99. 
Hsieh, C. -T. (1999), "Productivity Growth and Factor Prices in East Asia." American Economic Review 89, 133-138.

Hsieh, C. -T. (2000), "Measuring Biased Technological Change." Manuscript, Princeton University. Available at http://www.wws.princeton.edu/ chsieh/DIVISIA4.pdf.

Hsieh, C. -T. (2002), "What Explains the Industrial Revolution in East Asia? Evidence from the Factor Markets." American Economic Review 92, 502-526.

Irwin, D. (1991), "Terms of Trade and Economic Growth in Nineteenth-Century Britain." Bulletin of Economic Research 43, 93-101.

Imlah, A. (1958), Economic Elements in the Pax Britannica. Cambridge, MA.

Jackson, R. V. (1990), "Government Expenditure and British Economic Growth in the 18th-Century - Some Problems of Measurement.” Economic History Review 43, 217 235.

Jackson, R. V. (1992), "Rates of Industrial Growth during the Industrial Revolution." Economic History Review 45, 1-23.

John, A. H. (1953), "Insurance Investment and the London Money Market of the 18th Century." Economica 20, 137-158.

Lindert, P. H., and Williamson, J. G. (1983), "English Workers' Living Standards during the Industrial Revolution: A New Look.” Economic History Review 36, 1-25.

Lindert, P. H., and Williamson, J. G. (1985), "English Workers Real Wages: Reply to Crafts." Journal of Economic History 45, 145-153.

Mankiw, N., Romer, D., and Weil D. N. (1992), "A Contribution to the Empirics of Economic Growth." Quarterly Journal of Economics 107, 407-437.

McCloskey, D. N. (1972), "The Enclosure of Open Fields: Preface to a Study of Its Impact on the Efficiency of English Agriculture in the Eighteenth Century." Journal of Economic History 32, 15-35.

McCloskey, D. N. (1994), “1780-1860: A Survey.” In R. Floud and D. N. McCloskey (Eds.), The Economic History of Britain since 1700, vol. 1. Cambridge, $2^{\text {nd }}$ edition. Pp. 242-270.

Mirowski, D. (1981), "The Rise and Retreat of a Market: English Joint Stock Shares in the 18th Century." Journal of Economic History 41, 559-577.

Mitch, D. (1993), "The Role of Human Capital in the First Industrial Revolution." In J. Mokyr (Ed.), The British Industrial Revolution: An Economic Perspective. Boulder, Colorado. Pp. 267-307.

Mitchell, B. R. (1971), Abstract of British Historical Statistics. Cambridge.

Mokyr, J. (1987), "Has the Industrial Revolution Been Crowded Out?" Explorations in Economic History 24, 293-319.

Mokyr, J. (1999). "Editor's Introduction." In J. Mokyr (Ed.), The British Industrial Revolution: An Economic Perspective. Boulder, Colorado, $2^{\text {nd }}$ edition. Pp. 1-127.

Neal, L. (1994), "The Finance of Business during the Industrial Revolution.” In R. Floud and D. N. McCloskey (Eds.), The Economic History of Britain since 1700, vol. 1. Cambridge, $2^{\text {nd }}$ edition. Pp. 151-81.

Nelson, R. R. (1964), "Aggregate Production Functions and Medium-Range Growth Projections." American Economic Review 54, 575-606.

Nordhaus, W. D. (1997), "Do Real-Output and Real-Wage Measures Capture Reality? The History of Lighting Suggests Not." In T. Bresnahan and R. Gordon (Eds.), The Economics of New Goods. Chicago. Pp. 29-66. 
Presnell, L. S. (1960), Studies in the Industrial Revolution. London.

Romer, D. (1996), Advanced Macroeconomics. New York.

Schofield, R. (1973), "Dimensions of Illiteracy, 1750-1850." Explorations in Economic History 10, 437-454.

Temin, P. (1997), "Two Views of the British Industrial Revolution." Journal of Economic History 57, 63-82.

Temin, P. (2000), "A Response to Crafts and Harley.” Journal of Economic History 60, 842-846.

Turner, M. E., Beckett, J. V., and Afton, B. (1997), Agricultural Rent in England, 16901914. Cambridge.

Turner, M. E., Beckett, J. V., and Afton, B. (1998), "Renting the Revolution: A Reply to Clark." Journal of Economic History 58, 211-219.

Voth, H. -J. (1998), "Time and Work in Eighteenth-Century London." Journal of Economic History 58, 29-58.

Voth, H. -J. (2001), Time and Work in England, 1750-1830. Oxford.

Williamson, J. G. (1984), "Why was British Growth So Slow During the Industrial Revolution?" Journal of Economic History 44, 687-712. 


\section{Appendix: Expectations formation and factor prices}

Expectations can have an impact on our estimates in two ways. First, if agents anticipate the relative price of capital goods to change, we need to modify the standard HallJorgenson formula (Collins and Williamson, 2001). Second, ex ante and ex post rental rates of capital, land rentals and wages might diverge.

The simple Ramsey-Cass-Koopmans model of growth takes the rental rate of capital to be equal to the real interest rate plus depreciation. The basic underlying assumption of the model is that output and capital are de facto the same good, i.e. the proportion of output that is saved every period is transformed one to one into capital for the following period. This implies that in this model, the price of capital relative to output is 1 by construction.

In reality, however, the existence of adjustment costs and other such 'imperfections', cause the relative price of capital to vary over time. Hall and Jorgenson (1967) derived an expression for the rental rate of capital in such environments. They start with the nonarbitrage condition that the relative price of a new capital good (i.e. its

price relative to the numeraire output) has to be equal to the discounted value of all future services derived from this capital good:

$$
\begin{aligned}
& v(t)=\int_{t}^{\infty} e^{-(i-\pi+\delta)(s-t)} r(s) d s \\
& v(t)=\frac{p_{K}(t)}{p(t)}
\end{aligned}
$$

Differentiating this formula with respect to the time of acquisition ( $\mathrm{t}$ ) and assuming static expectations about the price of investment we get the so-called Hall-Jorgenson formula:

$$
r=v(i-\pi+\delta)
$$

which states that the real rental rate of capital is equal to the relative price of capital times the real interest plus depreciation. 
Now if expectations are not static, that is if people expect the relative price of capital to vary through time, then (assuming perfect foresight) differentiation of (1) yields:

$$
r=v(i-\pi+\delta)-\dot{v}
$$

which can be expressed as:

$$
r=v\left(i-\pi+\delta-\frac{\dot{v}}{v}\right)
$$

Hence non-static expectations add a corrective term to equation (3) equivalent to the change in the relative price of capital over the period.

\begin{tabular}{|c|c|c|c|c|c|c|c|}
\hline estimate & & $\begin{array}{c}\text { percentage } \\
\text { rate of } \\
\text { change }\end{array}$ & $\begin{array}{l}\text { cost of } \\
\text { capital }\end{array}$ & labour & $\begin{array}{l}\text { land } \\
\text { rents }\end{array}$ & $\begin{array}{l}\text { govern- } \\
\text { ment }\end{array}$ & $\begin{array}{c}\text { TFP } \\
\text { Growth }\end{array}$ \\
\hline \multicolumn{4}{|l|}{ preferred } & 0.35 & 0.26 & 2.60 & 0.27 \\
\hline & & $1801-1830$ & 0.71 & 0.25 & 0.76 & 1.11 & 0.54 \\
\hline & & $1831-1860$ & -0.21 & 0.68 & 0.48 & 0.31 & 0.33 \\
\hline \multicolumn{8}{|c|}{$\begin{array}{l}\text { relative price } \\
\text { of capital } \\
\text { corrected }\end{array}$} \\
\hline & 2 & $1770-1800$ & -0.91 & 0.35 & 0.26 & 2.60 & 0.10 \\
\hline & & $1801-1830$ & 0.88 & 0.25 & 0.76 & 1.11 & 0.60 \\
\hline & & $1831-1860$ & 0.24 & 0.68 & 0.48 & 0.31 & 0.48 \\
\hline
\end{tabular}

Table A. 1: Impact of expectations about relative price of capital on TFP estimates

Table A.1 demonstrates that some of our conclusions would even be strengthened if we assume rational expectations about the future evolution of the relative price of capital goods. We use the preferred estimate as a basis of comparison. TFP growth in the first period would even weaker, and the acceleration after 1800 would be slightly sharper. For the final period, we also find somewhat higher rates of productivity growth. 
It is standard practice in contemporary economic studies to use ex post real interest rates, land rentals and wage rates in the calculation of the cost of capital and labour. To what extent can we be certain that ex post and ex ante factor prices did not diverge at the time of the Industrial Revolution? If accidental shocks to the value of money determined the distribution of income generated by production, we may impart an important bias to our estimates. Since we average for periods of 10 years, the chances that one-off changes in inflation will have a significant impact are small. At the same time, money wages and interest rates showed substantial nominal inertia at the time. To continue the sensitivity analyses carried out in the main part of this paper, we estimate the ex ante rate of inflation. We follow the approach of Barro and Sala-i-Martin, estimating ARMA $(1,1)$ models of inflation. ${ }^{76}$ Thus, only past inflation enters the expectations formation process. Barro and Sala-i-Martin show that their estimates track inflationary expectations as indicated in surveys relatively well. ${ }^{77}$ Similar models have been widely used in historical studies as well - such as in an analysis of expected inflation during the Great Depression in the U.S. ${ }^{78}$ The obvious alternative would have been to extract expectations from Mishkin-style regressions. Implementation of this appraoch requires the assumption that economic data such as growth rates are made available to economic agents in a timely fashion - clearly an unrealistic assumption for the eighteenth and early nineteenth centuries.

We derive the following ARMA model, using the Clark GDP deflator as a dependent variable:

$\mathrm{P}=87.69+0.85 \operatorname{AR}(1)-0.54 \mathrm{MA}(1)$

where $\mathrm{P}$ is the price level, $\mathrm{AR}$ is the lagged dependent variable, MA is the moving average component, and t-statistics are given in parentheses. Note that are parameter estimates are very similar to the ones obtained by Barro and Sala-i-Martin. The fitted values from the ARMA model can be then used as predictions of the future price level to

\footnotetext{
${ }^{76}$ Barro and Sala-i-Martin (1990, p. 15-7). We do this for both the Feinstein series and the Clark GDP deflator.

${ }^{77}$ Barro and Sala-i-Martin (1990, Figure 1, p. 16).
} 
calculate ex ante real rates. Table A. 2 compares the real interest rates and wages, as derived from the ARMA model predictions. The ex ante estimates of the real wage and the real land rental show higher growth for the first and second periods, and slower growth than in our ex post calculations thereafter. Similarly, the rental rate of capital falls less in the first thirty years, grows faster in the second period and then declines by the same amount as with ex-post rates between 1830 and $1860 .^{79}$

Table A. 2: Ex post and ex ante real interest rates

\begin{tabular}{lcccccc}
\hline & $\begin{array}{c}\text { ex post } \\
\text { capital } \\
\text { rental }\end{array}$ & $\begin{array}{c}\text { ex ante } \\
\text { capital } \\
\text { rental }\end{array}$ & $\begin{array}{c}\text { ex post } \\
\text { real } \\
\text { wage }\end{array}$ & $\begin{array}{c}\text { ex ante } \\
\text { real } \\
\text { wage }\end{array}$ & $\begin{array}{c}\text { ex post } \\
\text { real land } \\
\text { rental }\end{array}$ & $\begin{array}{c}\text { ex ante } \\
\text { land } \\
\text { rental }\end{array}$ \\
\cline { 2 - 7 } $\mathbf{1 7 7 0 - 9}$ & 100 & 95 & 100 & 95 & 100 & 95 \\
$\mathbf{1 8 0 0 - 9}$ & 89 & 89 & 111 & 114 & 108 & 111 \\
$\mathbf{1 8 3 0 - 9}$ & 110 & 115 & 120 & 124 & 136 & 140 \\
$\mathbf{1 8 6 0 - 9}$ & 103 & 108 & 147 & 148 & 157 & 157 \\
\hline
\end{tabular}

Does the use of ex ante rates have an impact on the estimates of TFP growth?

Table A.3: Impact of ex-ante interest rates on TFP estimates

\begin{tabular}{lcrrrrrr}
\hline estimate & $\begin{array}{c}\text { percentage } \\
\text { rate of } \\
\text { change }\end{array}$ & $\begin{array}{c}\text { cost of } \\
\text { capital }\end{array}$ & labour & $\begin{array}{c}\text { land } \\
\text { rents }\end{array}$ & $\begin{array}{c}\text { govern- } \\
\text { ment }\end{array}$ & $\begin{array}{c}\text { TFP } \\
\text { Growth }\end{array}$ \\
\cline { 3 - 8 } & 1 & $1770-1800$ & -0.40 & 0.35 & 0.26 & 2.60 & 0.27 \\
& $1801-1830$ & 0.71 & 0.25 & 0.76 & 1.11 & 0.54 \\
& $1831-1860$ & -0.21 & 0.68 & 0.48 & 0.31 & 0.33 \\
ex ante rates & 2 & $1770-1800$ & -0.23 & 0.60 & 0.50 & 2.84 & 0.49 \\
& $1801-1830$ & 0.85 & 0.27 & 0.78 & 1.12 & 0.60 \\
& $1831-1860$ & -0.21 & 0.60 & 0.39 & 0.22 & 0.27 \\
\hline
\end{tabular}

Just as in the case of earlier sensitivity analysis, we find that the possible use of alternative time series does not undermine our conclusions. With ex ante interest rates, productivity growth during the first period would be somewhat faster. In the second period, England's productivity performance remains below any sensible standard for fast growth, before declining to $0.27 \%$ in the last period.

\footnotetext{
${ }^{78}$ Cecchetti (1992).

${ }^{79}$ Note that the movement of the capital rental is influenced by the relative price of capital goods as well as the real interest rate, and should therefore not move in parallel with the alternative estimates of the wage and land rental series.
} 